\title{
Militêre Professionalisme en die Onderrig van Krygsgeskiedenis in die Suid-Afrikaanse Nasionale Weermag: 'n Historiese Perspektief'
}

\author{
LT.KOL. G.E. VISSER \\ Militêre Akademie, Fakulteit Krygskunde, Universiteit van Stellenbosch
}

\section{ABSTRACT}

\section{Military Professionalism and the Tuition of Military History in the South African National Defence Force: an Historical Perspective}

From an occupational point of view, the study of military history serves three main purposes. Firstly, military history is used in a practical or utilitarian fashion to foster esprit de corps or to derive military lessons from past wars. Secondly, military history, like other subjects, is studied at tertiary level for its educational value. In the third place, and in a way linked to both the aforementioned functions, knowledge of military history is an important element of military professionalism. The management of violence, which has traditionally been considered the unique (professional) skill of military officers, is in a continuous process of development and it is generally accepted that the military professional must have some knowledge and understanding of the historical development of that process in order to keep pace with his/her profession. The issue is how much knowledge of military history does the military officer require to be a true professional, and on which level must military history be studied for that purpose? From a scientific point of view, true military professionalism would demand the study of military history at university level, so as to enable the military officer to approach the subject with full knowledge of both its potential and its limitations. In view of its perceived occupational value, military history is indeed taught on various levels at military training and educational estab-

1 Hierdie artikel is ' $n$ uitbreiding en verwerking van die skrywer se bydrae tot ' $n$ referaat met die titel 'Die Onderrig van Krygsgeskiedenis in die Beroepswêreld' wat op 10 Jan. 1996 te Potchefstroom saam met T.D. Potgieter gelewer is tydens ' $n$ gesamentlike konferensie van die Historiese Genootskap van Suid-Afrika en die Suid-Afrikaanse Vereniging vir Geskiedenisonderrig oor die tema Geskiedenisleerplanne: Historiografiese Tendense en Onderrigmetodes. 
lishments throughout the world. In South Africa, military history has been taught on various officers' courses since the days of the Union Defence Force. It was initially taught on a more utilitarian level, but since the inception of the Military Academy in 1950, also on university level. Military History, with its main emphasis on the evolution of warfare through the ages, was initially seen as a cornerstone of military education and was a compulsory subject for all undergraduate courses at the Military Academy. Since the early 1960s, however, the emphasis on Military History declined to the point where it is currently no longer a compulsory subject for any course at the Military Academ. Military history also received very little systematic attention at other military training establishments in South Africa until 1996, when a process was started to introduce meaningful tuition of military history at the various SANDF Colleges as part and parcel of officers' development. However, the fact that Military History is not a compulson subject at the Military Academy, suggests that there is still no full recognition of the value of military history and its relationship to military professionalism within the South African National Defence Force. Military History should be re-introduced as compulsory subject for all undergraduate students at the Military Academy. This will satisfy the demand of true military professionalism for military history to be studied at an academic level and will provide the SANDF with a pool of qualified officers to optimize the teaching of military history at other SANDF training establishments. Military professionalism will thus be enhanced throughout the Defence Force and SANDF members enabled to maintain themselves in an international milieu where a sound knowledge of military history is accepted as an ipso facto component of the accoutrements of the military professional.

\section{INLEIDING}

Daar word algemeen aanvaar dat 'n studie van die krygsgeskiedenis uit ' $n$ beroepsoogpunt drie hooffunksies vervul: dit word eerstens op 'n praktiese wyse aangewend om esprit de corps te bevorder, lesse uit die oorloë van die verlede te leer en beginsels van oorlogvoering te formuleer/doktrines te ontwikkel; tweedens, word die krygsgeskiedenis, soos ander akademiese vakke, op tersiêre vlak ter wille van sy opvoedkundige waarde bestudeer; en, in die derde plek, baie nou verwant aan beide voormelde funksies, vorm ' $n$ kennis van die krygsgeskiedenis ' $n$ uiters belangrike element van militêre professionalisme. In hierdie artikel sal daar op die derde funksie van die krygsgeskiedenis, spesifiek die onderrig van krygsgeskiedenis in diens van militêre professionalisme, gekonsentreer word. Daar sal eerstens ' $n$ kort omskrywing van die begrippe krygsgeskiedenis en militêre professionalisme gegee word en aangetoon word hoe dié twee met mekaar in verband staan. Daarna sal daar in die lig van die verband tussen ' $n$ kennis van die krygsgeskiedenis en militêre professionalisme ' $n$ historiese perspektief van die onderrig van krygsgeskiedenis in die Suid-Afrikaanse Nasionale Weermag en sy voorgangers, spesifiek die voormalige Suid- 
Afrikaanse Weermag (SAW) en Umkhonto weSizwe $(\mathrm{MK})^{2}$, gegee word. Die hoofklem sal in hierdie verband op die onderrig van krygsgeskiedenis aan die Militêre Akademie, oftewel die Fakulteit Krygskunde van die Universiteit van Stellenbosch, val.

\section{WAT IS KRYGSGESKIEDENIS?}

Die krygsgeskiedenis kan breedweg gedefinieer word as daardie deel van die opgetekende menslike verlede wat met oorlogvoering in verband staan. Die vakgebied strek egter veel wyer as bloot die geskiedenis van militêre operasies as sodanig, aangesien faktore soos die sosiale, ekonomiese en politieke omstandighede van oorlogvoerende partye ook ' $n$ belangrike invloed op oorlogvoering uitoefen - en andersom. ${ }^{3}$ Die krygsgeskiedenis fokus dus op die wyse waarop state (en ook georganiseerde groepe, bv rewolusion re bewegings) vir oorlog voorberei; hoe hulle oorloë voer en beëindig; hoe sosiale, ekonomiese en politieke faktore die voorbereiding vir en die voer van oorloë beïnvloed; hoe die voorbereiding vir en die voer van oorloë gemeenskappe beïnvloed; hoe state die vredestydse funksies van weermagte bepaal en reguleer; en hoe die militêr en die gemeenskap mekaar wedersyds in vredestyd beïnvloed. ${ }^{4}$ Ingebed in al hierdie fasette van die krygsgeskiedenis is ook die soldaat se belewing van sy/haar beroep, onder meer sy/haar vrese en lyding op die slagveld, sy/haar persoonlike interaksie as uniformdraer met sy/haar omgewing en die invloed wat sodanige faktore op sy/haar handelinge in vrede en oorlog het. Die studieveld van die krygsgeskiedenis is dus nie alleen feitlik net so wyd as dié van die algemene geskiedenis nie, maar vertoon ook raakvlakke met verskeie ander dissiplines.

\section{WAT BEHELS MILITÊRE PROFESSIONALISME?}

Die terme "professioneel" en "(militêre) professionalisme" duik dikwels in gesprekke in en oor die SANW op, sonder dat dit altyd duidelik is wat die spreker presies daarmee bedoel. Dit wil egter voorkom asof daar normaalweg met professionele optrede bedoel word dat ' $n$ persoon sy taak tegnies en eties korrek en doeltreffend verrig. Die Concise Oxford

2 Hoewel die weermagte van die voormalige sogenaamde onafhanklike swart state, asook voormalige niestatutêre militêre magte anders as MK, ook as voorgangers van die Suid-Afrikaanse Nasionale Weermag gereken moet word, is hulle nie by hierdie studie ingesluit nie, aangesien hul hantering van die krygsgeskiedenis na skrywer se mening nie noemenswaardig van dié van die voormalige SAW en MK afgewyk het nie. ' $n$ Gebrek aan geredelik beskikbare bronne het egter ook bygedra tot die besluit om genoemde magte vir die doel van hierdie studie buite rekening te laat.

3 M. Blumenson, 'Why Military History? : To Analyze the Past, Discover the Present', Army (Jan. 1975), 35; W.F. Craven, 'Why Military History?', in H.R. Borowski, ed., The Harmon Memorial Lectures in Military History, 1959-1987 (Washington, D.C., 1988), 12, 14-15; G.E.Visser, 'Die Aard, Studieveld en Funksie van die Krygsgeskiedenis', Militaria, 23, 2 (1993), 3.

4 T.E. Griess, 'A Perspective on Military History', in J.E. Jessup, Jr and R.W. Coakley, A Guide to the Study and Use of Military History (Washington, D.C., 1980), 31; Blumenson, 'Why Military History?, 34-6; Visser, 'Die Aard, Studieveld en Funksie van die Krygsgeskiedenis', 3. 
Dictionary $5^{5}$ definieer 'n professie as "a vocation or calling, especially one that involves some branch of learning or science" en professionalisme as "the qualities or stamp of a profession". J.F. Votaw, wat duidelik, soos uit onderstaande bespreking sal blyk, by S.P. Huntington en H.D. Lasswell ${ }^{6}$ gaan kers opsteek het, definieer militêre professionalisme kortweg as "... an attitude or state of mind distinguishing the expert from the amateur. The military professional is an expert in the management of violence and is characterized by his sense of responsibility to his men and to the state."

Die frase "an attitude or state of mind" in Votaw se definisie van militêre professionalisme is tekenend van ' $n$ bepaalde mate van vaagheid wat dié konsep omgewe en dié dilemma waarin die navorser hom bevind as hy probeer om die aard en inhoud van militêre professionalisme vas te vat. Sam C. Sarkesian, skryf in dié verband:

"... the concept of military profession ... is clouded in emotional issues and at best is only slightly susceptible to empirical analysis. Dealing with attitudes and images, obscure boundaries, and a number of political-psychological facets, military professionalism is, in the main, an amalgam of ambiguous, pseudo-scientific rationale, traditional heroics, and organizational politics."

Soos ook uit Votaw se definisie hierbo blyk, word daar te midde van die ietwat ondefinieerbare inhoud van militêre professionalisme nietemin algemeen aanvaar dat dit primêr op die korps van voltydse beroepsoffisiere betrekking het. Deeltyse (burgermag-) offisiere, spesialiste in uniform (bv. dokters), sowel as adjudant-offisiere, onderoffisiere en manskappe, is vanselfsprekend ook in ' $n$ mindere of meerdere mate verbind tot die waardes en norme wat met militêre professionalisme geassosieer word, ${ }^{9}$ maar dit is die beroepsoffisiere wat die toon aangee, die professionele standaarde bepaal en die professionele beeld skep. ${ }^{10}$

S.P. Huntington, wie se monumentale werk, The Soldier and the State (1957), volgens Sarkesian ' $n$ aansienlike invloed uitgeoefen het op diegene wat die afgelope paar dekades oor die aard van militêre professionalisme geskryf het, ${ }^{11}$ som die kenmerke van "n professie op as "... its expertise, responsibility and corporateness." 12 Volgens hom beskik die profes-

H.W. Fowler and F.G. Fowler, eds., The Concise Oxford Dictionary of Current English, 5th edition (Oxford. 1964).

6 S.P. Huntington, The Soldier and the State: The Theory and Politics of Civil-Military Relations (Cambridge, Massachusetts, 1957); H.D. Lasswell, 'The Garrison State', American Journal of Sociology, 46 (1941).

7 J.F. Votaw, 'An Approach to the Study of Military History', in Jessup and Coakley, A Guide to the Stucth and Use of Military History, 48.

8 S.C. Sarkesian, Beyond the Battlefield: the New Military Professionalism (New York, etc., 1981), 164.

9 Huntington, The Soldier and the State, 11-12, 15, 17; M. Nuciari, 'Rethinking the Military Profession: Models of Change Compared', Current Sociology, 42, 3 (Winter 1994), 9; C.C. Moskos, 'Institutional and Occupational Trends in Armed Forces', in C.C. Moskos and F.R. Wood, eds., The Military: More Than Just a Job.' (Washington, etc., 1988), 16.

10 Sarkesian, Beyond the Battlefield, 166; vergelyk ook Huntington, The Soldier and the State, 11-13, $17-18 \mathrm{en}$ M.R. Malan, 'Civilian Supremacy over the Military: Guidelines for Embryonic Democracies' (Unpublished M.A. thesis, University of Stellenbosch, 1994), 16,30.

1 Sarkesian, Beyond the Battlefield, 165.

12 Huntington, The Soldier and the State, 8. 
sionele persoon, of dit nou 'n dokter, teoloog, of regsgeleerde is, oor gespesialiseerde kennis en vaardighede op ' $n$ bepaalde terrein van die menslike strewe, wat hy/sy verkry het deur middel van langdurige opvoeding en ondervinding. Die professionele persoon lewer ' $n$ unieke, deskundige diens wat essensieel is vir die funksionering van die gemeenskap waarin hy/sy hom/haar bevind en daarom rus daar 'n sosiale verpligting op hom/haar om dié diens te lewer wanneer daar ' $n$ behoefte daaraan ontstaan. Die lede van 'n professie ervaar vanweë hul gespesialiseerde opleiding, opvoeding, kennis en vaardighede, asook die sosiale verpligting wat daar op hulle rus, 'n gevoel van samehorigheid en sien hulself as groep wat duidelik van leke op hul gebied onderskei kan word. ${ }^{13}$

Teoretici is dit eens dat offisierskap aan al drie bogenoemde vereistes vir professionalisme voldoen, maar dat militêre professionalisme ook 'n verdere, unieke kenmerk, wat met die sosiale verpligting van die offisier saamhang, vertoon: die tradisie van ridderlikheid en militêre eer en glorie. ${ }^{14}$ Janowitz (1966) skryf in dié verband :

"... traditionally, officers have not fought primarily because of an explicit political ideology. On the contrary, the political interest of the typical officer have been intermittent at best. Only at the higher ranks and among its elite members is there a more sustained concern with the political purposes of the military establishment. 'Honor' is the basis of its belief system.

"Military honor is both a means and an end. The code of honor specifies how an officer ought to behave, but to be 'honorable' is an objective to be achieved for its own right. When military honor is effective, its coercive power is considerable, since it persistently points to a single over-riding directive: The professional soldier always fights...

"Military honor meant, first, officers were gentlemen; second, fealty to the military commander was personal; third, officers were members of a cohesive brotherhood which claimed the right to extensive self-regulation; and fourth, officers fought for the preservation and enhancement of traditional glory."15

Harold Lasswell (1941) definieer die professionele deskundigheid van die militêre offisier as "die bestuur van geweld." 16 Huntington onderskryf hierdie definisie; hy sien die funksie van 'n militêre mag as suksesvolle oorlogvoering en die taak van die offisier as die organisering, uitrusting en opleiding van dié mag, asook die beplanning van sy aktiwiteite en die bestuur van sy optrede binne en buite die geveg. Die besondere deskundigheid van die offisier is dus die bestuur, aanwending en beheer van 'n menslike organisasie waarvan

Huntington, The Soldier and the State, 11-18; J.A. Williams, 'The International Image of the Military Professional', African Security Review, 4, 5 (1995), 24-6; R.A. Preston, 'Perspectives in the History of Military Education an Professionalism', in H.R. Borowski, ed., The Harmon Memorial Lectures in Military History, 1959-1987 (Washington, D.C., 1988), 271; vergelyk ook Sarkesian, Beyond the Battlefield, 6-9.

M. Janowitz, The Professional Soldier : A Social and Political Portrait (New York, 1966), 216, 217.

Lasswell, 'The Garrison State', 455, 458, 463. 
die primêre funksie die toediening of fisiese aanwending van geweld is. ${ }^{17}$ Die gewone soldaat, daarenteen, is ' $n$ spesialis in die toediening of fisiese aanwending van geweld en nee in die bestuur daarvan nie; daarom is sy/haar beroep ' $n$ ambag en nie ' $n$ professie nie. ${ }^{18}$

Meer resente skrywers, soos S.C. Sarkesian, M. Janowitz en C. Moskos, verskil weliswaar in sekere opsigte van Huntington se siening van militêre professionalisme, veral deurdat hulle, naas die institusionele motief van offisierskap (patriotisme, sosiale verpligting, ens.), ook die loopbaanmotief (salarisoorwegings, vorderingsmoontlikhede, byvoordele, ens.) beklemtoon, ${ }^{19}$ d.w.s. die tradisionele versus die transformele opvatting van offisierskap. Hulle onderskryf egter steeds die basiese elemente van Huntington se siening van militêre professionalisme op grond daarvan dat "occupational considerations ... cannot provide the basis for a successful military establishment". ${ }^{20}$

Alles in ag genome, wil dit dus voorkom of militêre professionalisme vandag daarop neerkom dat die offisier onder alle omstandighede korrek en ridderlik moet optree; sy haar taak korrek en effektief moet kan uitvoer; die grootste moontlike mate van insig, gebaseer op ' $n$ deeglike, parate kennis van sy/haar beroep, in sy/ haar taak (en professie) aan die dag moet lê; en met gesag oor sy/haar professie moet kan gesels en argumenteer. Dit beteken dat die professionele offisier nie net sy/haar taak tegnies korrek moet kan uitvoer nie, maar ook baie deeglik bewus moet wees van die milieu waarbinne hy/sy opereer - hy/sy moet dus, onder andere, sy/haar taak in in die breë perspektief van burgerlik-militère verhoudings binne ' $n$ demokratiese gemeenskap sien.

\section{HOE WORD MILITÊRE PROFESSIONALISME DEUR 'N KENNIS VAN DIE KRYGSGESKIEDENIS GERAAK?}

Wanneer ' $n$ mens die literatuur oor militêre professionalisme bestudeer, word dit baie gou duidelik dat daar vry algemeen aanvaar word dat daar ' $n$ baie sterk verband tussen militêre professionalisme en ' $n$ kennis van die krygsgeskiedenis bestaan; tewens, dat 'n kennis van die krygsgeskiedenis inderdaad as die hoeksteen van militêre professionalisme beskou word. Die alombekende R.E. en T.N. Dupuy stel dit onomwonde dat

"The emergence of military professionalism came hand in hand with the appearance of coherent and scientific military theory. This theory became the basis for systematic military education, at graduate and undergraduate level, an essential element for professionalism in the modern sense. The products of this educational

17 Huntington, The Soldier and the State, 11.

18 Huntington, The Soldier and the State, 11-13, 17-18.

19 Williams, 'The International Image of the Military Professional', 24-6; Vergelyk ook Sarkesian, Beyond the Battlefield, 6-9, 165, 184, Moskos, 'Institutional and Occupational Trends in Armed Forces', 15-25 en Malan, 'Civilian Supremacy over the Military', 28-30, 132-135.

20 Williams, 'The International Image of the Military Professional', 25. 
system then became members of a highly specialized group of professionals, the practitioners of the theory." 21

Die coherent and scientific military theory, oftewel professionele militêre kennis, waarna Dupuy and Dupuy verwys, berus in geen geringe mate op ' $n$ kennis van die krygsgeskiedenis; soos die kursusleerplan van die alombekende British Army Staff College, Camberley, dit kortweg stel: "the bulk of military knowledge is contained in military history ... It (military history) will help lead you to the essential truths of our profession." ${ }^{22}$ Huntington onderstreep hierdie opvatting as hy skryf:

"Professional knowledge has a history, and some knowledge of that history is essential to professional competence ... The management of violence is not a skill which can be mastered simply by learning existing techniques. It is in a continuous process of development, and it is necessary for the officer to understand this development and to be aware of its main tendencies and trends. Only if he is aware of the historical development of the techniques of organizing and directing military forces can the officer expect to stay on top of his profession. The importance of the history of war and military affairs receives sustained emphasis throughout military writing and military education ... The military vocation is a profession because it has accumulated experiences which make up a body of professional knowledge. In the military view man learns only from experience. If he has little opportunity to learn from his own experience, he must learn from the experience of others. Hence, the military officer studies history ... The military ethic thus places unusual value upon the ordered, purposive study of history." ${ }^{23}$

T.E. Griess sluit ten nouste by Huntington aan. Hy skryf:

"A wide and critical reading of military history can help the soldier define and appreciate the meaning of professionalism. Personal understanding will be shaped by learning what others have used as yardsticks in the past. Broad study and careful reflection on earlier views will also encourage analysis of the military ethic which can stimulate useful discussion of that ethic with others who may be less well informed. What obligations does professionalism require? How do the demands of war determine the nature of military professionalism? How does one educate oneself for the grave responsibilities of leadership on the battlefield? History can provide answers to these questions." ${ }^{24}$

Sarkesian stel insgelyks ' $n$ kennis van die geskiedenis (en dus ook die krygsgeskiedenis) sentraal in sy definisie van militêre professionalisme as hy "n "sense of history" eerste

21 R.E. Dupuy and T.N. Dupuy, The Collins Encyclopedia of Military History, 4th ed. (Glasgow, 1993), 811.

22 Course Curriculum Army Staff College, Camberley, uittreksel verskaf deur lt.kol. A. Ellis, S.A. Leërkollege, Pretoria, Mrt. 1996.

23. Huntington, The Soldier and the State, 8, 13-14, 64.

24 Griess, 'A Perspective on Military History', 34. 
aanstip op sy lys van die basiese "intellectual baggage of every (military) professional". ${ }^{25}$

Dit is egter moeilik om die verband tussen 'n kennis van die krygsgeskiedenis en militêre professionalisme te konkretiseer. Miskien is die beste manier om dit te verduidelik te vinde in E.N. Luttwak ${ }^{26}$ se uitspraak dat dit nie moontlik is om te bewys dat die groot militêre leiers van die verlede hul krygskuns (oftewel professionalisme) enigsins aan 'n studie van die krygsgekiedenis te danke gehad het nie, maar dat wel bewys kan word dat hulle feitlik sonder uitsondering soveel krygsgeskiedenis gelees het as wat hulle kon; daarom is daar vir die professionele offisier "... no excuse for willfully ignoring the record of human experience at war when preparing to assume responsibility for its conduct - at any level." ${ }^{27}$ T.D. Potgieter ${ }^{28}$ het dan ook in " $n$ onlangse studie bevind dat militêre akademies in die buiteland feitlik sonder uitsondering krygsgeskiedenis (hoewel soms onder die vaandel van vakke soos Algemene Geskiedenis of Strategie) as ' $n$ verpligte vak vir alle studente aanbied. Daarby vorm krygsgeskiedenis, aldus Potgieter, normaalweg ook ' $n$ integrale deel van die stafkursusse van alle moderne weermagte. Die British Army Staff College, Camberley, om maar een voorbeeld te noem, lê soveel klem op die waarde van krygsgeskiedenis, dat hulle in 1987 ' $n$ pos vir 'n residenthistorikus by dié kollege geskep het. ${ }^{29}$

\section{HOEVEEL KENNIS MOET DIE PROFESSIONELE OFFISIER VAN DIE KRYGS- GESKIEDENIS HÊ EN OPWATTER VLAK/WYSE MOET KRYGSGESKIEDENIS ONDERRIG WORD?}

Daar kan in die lig van bogenoemde min twyfel oor die relevansie van die krygsgeskiedenis vir militêre professionalisme wees. Die vraag is egter op watter aspekte van die krygsgeskiedenis die offisier hom moet toespits, op welke wyse/op watter vlak die vak onder$\mathrm{rig} /$ bestudeer moet word en hoeveel kennis die offisier van die krygsgeskiedenis moet hê om werklik professioneel te wees? Wat eersgenoemde vraag betref, identifiseer B.F. Cooling $\mathrm{III}^{30}$ tien velde ("areas") in die krygsgeskiedenis as 'Military History for the Military Professional', terwyl J.F. Votaw ${ }^{31}$ op sy beurt tien deurlopende temas ("threads of continuity") aanstip wat teen 1980 by die United States Military Academy, West Point, as basis vir die bestudering van die krygsgeskiedenis gebruik is. Dié velde word kortliks in Tabel 1 hieronder saamgevat.

26 E.N. Luttwak, 'Introduction', in L.J. Matthews and D.E. Brown, eds., The Parameters of War: Military History from the Journal of the U.S. Army War College (Washington, etc., 1987), xvi; vergelyk ook B.F. Cooling,

'Military History for the Military Professional', in Matthews and Brown, The Parameters of War, 23.

Luttwak, 'Introduction', xvi.

T.D. Potgieter in Visser en Potgieter 'Die Onderrig van Krygsgeskiedenis in die Beroepswêreld'.

Course Curriculum Army Staff College, Camberley.

Cooling, 'Military History for the Military Professional', 22-27.

Votaw, 'An Approach to the Study of Military History', 47-48. 


\begin{tabular}{|c|c|}
\hline B.F. Cooling III & J.F. Votaw \\
\hline $\begin{array}{l}\text { Ten Areas of Military History for the } \\
\text { Military Professional }\end{array}$ & $\begin{array}{l}\text { Ten Threads of Continuity in Military His- } \\
\text { tory: West Point }\end{array}$ \\
\hline 1. Nature and Scope of Military History. & 1. Military Theory and Doctrine. \\
\hline 2. Armed Forces and Society. & 2. Military Professionalism. \\
\hline 3. Command and Control. & 3. Generalship. \\
\hline $\begin{array}{l}\text { 4. Human Composition of Military } \\
\text { Forces. }\end{array}$ & 4. Strategy. \\
\hline 5. National Security Policies. & 5. Tactics. \\
\hline $\begin{array}{l}\text { 6. Interaction of Military, Political and } \\
\text { Diplomatic Affairs. }\end{array}$ & 6. Logistics and Administration. \\
\hline 7. Internal Crisis and Military Force. & 7. Technology. \\
\hline $\begin{array}{l}\text { 8. Nationbuilding Activities of the Mili- } \\
\text { tary. }\end{array}$ & 8. Political Factors. \\
\hline $\begin{array}{l}\text { 9. Unpopular Wars and Military Opera- } \\
\text { tions. }\end{array}$ & 9. Social Factors. \\
\hline 10. Technology, Culture and Warfare. & 10. Economic Factors. \\
\hline
\end{tabular}

Tabel 1. B.F. Cooling en J.F. Votaw se raamwerke vir die bestudering van die krygsgeskiedenis. (Die onderwerpe is gelys in die volgorde waarin die skrywers daarna verwys; daar is dus nie probeer om ooreenstemmende onderwerpe teenoor mekaar te plaas nie.)

Soos uit die tabel hierbo blyk, stem Cooling en Votaw, hoewel hulle verskillende opskrifte gebruik, se raamwerke vir die bestudering van die krygsgeskiedenis grootliks ooreen, maar is daar tog bepaalde verskille. Daar kan byvoorbeeld geargumenteer word dat militêre teorie ook die krygsgeskiedenis insluit, maar dat militêre professionalisme as sodanig, en in 'n mindere mate ook militêre strategie en taktiek, nie direk deur Cooling se raamwerk gedek word nie. Cooling en Votaw se raamwerke behoort dus saamgevoeg te word om ' $n$ volledige en bruikbare raamwerk vir die studie van die ewolusie van oorlogvoering (en dus ook van militêre professionalisme) deur die eeue te verkry. Soos

32 Cooling, 'Military History for the Military Professional', 22.; Votaw, 'An Approach to the Study of Military History’, 47, 48. 
beide Cooling en Votaw tereg opmerk, ${ }^{32}$ moet raamwerke soos dié wat hierbo uiteengesit is, nie op enige wyse verabsoluteer word nie - dit bly bloot ' $n$ nuttige instrument om die bestudering van die krygsgeskiedenis te organiseer of te fokus. Die verskillende onderwerpe is vanselfsprekend ook nie wedersyds uitsluitend nie, maar oorvleuel dikwels tot ' $n$ mindere of meerdere mate.

Oor die vraag op welke wyse/vlak die krygsgeskiedenis bestudeer moet word, reken Cooling dat die offisier dit óf in die klaskamer, óf op sy/haar eie kan bestudeer. Sarkesian, daarenteen, voer aan dat die sogenaamde "intellektuele bagasie" van die offisier nie courses of instruction is nie, maar wel intellectual insights and understanding en dat alhoewel offisiere dit deels op eie inisiatief deur selfstudie kan bekom, die verwerwing daarvan ' $n$ integrale deel van normale offisiersontwikkeling behoort te wees. ${ }^{33}$ Uit ' $n$ wetenskaplike oogpunt kan geargumenteer word dat ware militêre professionalisme vereis (soos ook deur die aanhaling uit Dupuy and Dupuy hierbo gesuggereer word) dat dit op universiteitsvlak bestudeer moet word, ten einde die offisier in staat te stel om die vak met volle begrip van beide sy moontlikhede en sy beperkings te benader; die ander geleerde professies, byvoorbeeld die medisyne, regsgeleerdheid, ens, berus immers normaalweg ook op universitêre studie, sodat offisierskap kwalik op dieselfde vlak vermeld kan word as dit nie ook op daardie fondament gevestig is nie. Dit wil egter nie sê dat daar nie 'n plek vir die onderrig van krygsgeskiedenis op ander vlakke binne die militêr is nie. Inteendeel, in soverre ' $n$ universiteitsgraad, waarby kursusse in krygsgeskiedenis ingesluit is, nie ' $n$ vereiste vir offisiersaanstelling is nie, is dit noodsaaklik dat daar vir die onderrig daarvan op die gewone offisierskursusse voorsiening gemaak sal word. Daar kan geargumenteer word dat adjudantoffisiere, onderoffisiere en manskappe ook op elementêre vlak onderrig in die krygsgeskiedenis behoort te ontvang, daar hulle sekere basiese normes en waardes van militêre professionalisme moet begryp en onderskryf.

Ongeag die vlak waarop krygsgeskiedenis in die militêr onderrig word, moet daar deur die onderrig daarvan by die soldaat, en veral die offisier, ' $n$ bewustheid gekweek word van die noodsaaklikheid daarvan om dwarsdeur sy/haar loopbaan die krygsgeskiedenis, spesifiek die resente krygsgeskiedenis, te bestudeer, ten einde op hoogte te bly van die nuutste ontwikkelinge met betrekking tot sy/haar professie. Hoe meer kennis die offisier van die krygsgeskiedenis het om sy/haar opleiding, opvoeding en ervaring aan te vul en in perspektief te plaas, hoe beter sal hy/sy toegerus wees om aan die eise van militêre professionalisme te voldoen soos hy/sy in die militêre hiërargie vorder, in die besonder wanneer hy/sy die hoogste rangsvlakke van sy/haar professie begin betree. ${ }^{34}$

34 Vergelyk Huntington, The Soldier and the State, 16-17. 


\section{DIE VESTIGING VAN KRYGSGESKIEDENIS AS HOEKSTEEN VAN MILITÊRE PROFESSIONALISME IN DIE UNIEVERDEDIGINGSMAG}

In Suid-Afrika was die opleiding van die offisiere (per definisie blank en manlik) van die Unieverdedigingsmag tot en met die Tweede Wêreldoorlog hoofsaaklik op funksionele militêre opleiding toegespits. ${ }^{35}$ Dat die kryggsgeskiedenis ook in hierdie benadering ingespan is, ly geen twyfel nie, soos uit onderstaande aanhaling uit ' $n$ brief van die Sekretaris van Verdediging aan die Sekretaris van Finansies blyk:

"In order to provide a text-book for Officers and more particularly students of the S.A. Military College, Roberts Heights, to study the Campaign of South West Africa in 1914 - 15, the Minister has requested Brigadier-General J.J. Collyer retired Chief of the General Staff Union Defence Forces - to write a general history of the principal operations conducted during the course of the Campaign with notes giving an appreciation of the situation at the time of the operations also details of operation orders issued together with explanations and criticism of the manner in which such orders were executed." 36

Dit was egter eers in 1947, toe die Unieverdedigingsmag 'n offisiersontwikkelingsfilosofie aanvaar het wat beklemtoon het dat offisierskap 'n professie eerder as ' $n$ beroep was en dus beide opleiding en opvoeding (studie) vereis het, dat die onderrig van die krygsgeskiedenis as hoeksteen van militêre professionalisme in Suid-Afrika tot sy reg gekom het. Dié nuwe offisiersontwikkelingsfilosofie het naamlik van die standpunt uitgegaan dat

“... the cadet (d.w.s. die aspirantoffisier) must not only be turned into an efficient soldier, but he must be trained so that 'each cadet shall have upon graduation, those qualities and attributes that are essential to his progressive and continued development throughout a life-time career as an officer of the South African Permanent Force' ... The training course is designed to bring out all the faculties of the officer cadet ... and to provide the professional background for his future career ... the focus of this whole conception, is that the cadet, although primarily a soldier, will in addition be trained to become a useful citizen. He will be taught to adapt himself with ease in whatever environment he may be thrown ... By accustoming him to discipline, self-control, prestige, tradition, esprit de corps and moral integrity, his character will be tempered. Obedience, punctuality, politeness and civility will become part of his temperament and personality, part of

35 Vergelyk C.M. Bakkes, Die Geskiedenis van die Suid-Afrikaanse Militêre Kollege, 1912-1955, 5-7 (SuidAfrikaanse Nasionale Weermag Argief (SANWA), Pamflette 99, Pamflet 3108, ongepubliseerde manuskrip).

SANWA, GOC UDF 18, brief G.O.C. 71/1936/183, Secretary for Defence - Secretary for Finance, 22 May 1936. (Verwysing goedgunstiglik verskaf deur lt.kol. I.J. van der Waag, Dept. Krygsgeskiedenis, Militêre Akademie.)

37 S.A. Militêre Kollege, The South African Military College / Die Suid-Afrikaanse Militêre Kollege (Pretoria, 1948), 23, 7,27, 28. (Vetdruk deur skrywer bygevoeg.) 


\section{his code of behaviour ..." ${ }^{37}$}

Die opleiding van kadette by die S.A. Militêre Kollege is met die oog op bogenoemde verbreed om ook vir opvoeding in akademiese vakke, soos Afrikaans, Engels, Staatsleer, Ekonomie, Sielkunde, Wiskunde, Fisika, Chemie en Krygsgeskiedenis (oftewel "Militêre Geskiedenis", soos dit destyds genoem is), voorsiening te maak. ${ }^{38}$ Dat 'n kennis van die krygsgeskiedenis onomwonde as die hoeksteen van militêre professionalisme erken is, blyk duidelik uit die sentrale, samebindende rol wat die nuwe opvoedingsfilosofie aan die onderrig van Krygsgeskiedenis in die kursusleerplan toegeken het. Die doel met die onderrig van die vak is naamlik omskryf as synde:

"... to form a framework, a setting for all the multitudinous subjects that are taught, the cadet will study military history, the development of the art of war and its governing principles, the continued evolution of battle formations, combined operations and logistics." ${ }^{39}$

Hierdie doelformulering het dus nie bloot die praktiese nutswaarde van die vak beklemtoon nie, maar het inderdaad ' $\mathrm{n}$ kennis van die krygsgeskiedenis sentraal in die professionele agtergrond van die offisier gestel - dit was die rigsnoer wat hom moes oriënteer in die breër omgewing waarin hy opereer. ' $\mathrm{n}$ Ander, baie belangrike, aspek van die nuwe opvoedingsfilosofie was dat dit daarop gemik was om 'n gesonde grondslag vir Krygsgeskiedenis en die ander akademiese vakke te lê, wat die offisier kon gebruik as basis om hom dwarsdeur sy loopbaan deur middel van selfstudie verder in dié dissiplines te skool. Langs dié weg is daar duidelik gehoop om "n kultuur van "lewenslange" studie by die jong offisier aan te kweek, ten einde te verseker dat die offisier dwarsdeur sy loopbaan sou bly ontwikkel ${ }^{40}$ en dus voortdurend in professionalisme sou toeneem.

\section{DIE ONDERRIG VAN KRYGSGESKIEDENISAAN DIE MILITÊREAKA- DEMIE, 1950-94}

Met die stigting van die Militêre Akademie onder die vleuels van die Universiteit van Pretoria in 1950, was Krygsgeskiedenis ("Militêre Geskiedenis") in albei studierigtings (B.A.(Mil.) en B.Sc.(Mil.)) op eerstejaarsvlak verpligtend. Krygsgeskiedenis was inderwaarheid aanvanklik slegs ' $n$ eerstejaarsvak, maar is in 1952 tot ' $n$ driejarige hoofvak vir die B.A. (Mil.)-graad uitgebrei. Dit was egter steeds net op eerstejaarsvlak verpligtend. Dit was insgelyks steeds ' $n$ verpligte vak vir alle B.Sc. (Mil.)-studente, met dié verskil dat

S.A. Militêre Kollege, The South African Military College, 23-25.

S.A. Militêre Kollege, The South African Military College, 26.

40 S.A. Militêre Kollege, The South African Military College, 27,

41 Universiteit van Pretoria (UP) Argief, Notule van die Raad 1952 Deel I (Jan.-Jun.), S. 7955, 'Wysiging van Leerplanne: B.A.(Mil.) en B.Sc.(Mil.)', 6 Nov. 1951; UP Argief, Notule van die Raad 1951, R. 3368, Notule van die gewone vergadering van die Raad gehou op 22 Nov. 1951 om $7.30 \mathrm{~nm}$., 6; Universiteit van Pretoria Jaarboek 1952, 98, 166. 
hulle nie op tweede- en derdejaarsvlak daarmee kon voortgaan nie. ${ }^{41}$ Van 1954 af kon Lugmagstudente in die B.Sc. (Mil.)-rigting egter op aanbeveling van die Lugstafhoof ' $n$ spesiale kursus volg waarin glad nie vir die aanbied van Krygsgeskiedenis voorsiening gemaak is nie..$^{42}$

Soos uit die doelformulering met betrekking tot die onderrig van Krygsgeskiedenis aan die Militêre Akademie blyk, het die vak in die militêre graadkursusse die sentrale, samebindende rol behou wat hy sedert 1947 in die kadetkursusse gespeel het. Die doel van die vak is naamlik in 1953 soos volg omskryf:

"Om alle werk wat op die kursus (d.w.s. die graadkursus as geheel) gedoen word te konsolideer en ' $n$ beeld van oorlogvoering in sy geheel te skep. Dit sluit in 'n studie van die ontwikkeling van die oorlogskuns en die beginsels wat dit beheer. 'n Studie word ook gemaak van internasionale verhoudings en wêreldorganisasie en kandidate word besiel met die ideaal om hul land te eer en dien deur ' $n$ studie van die nasionale geskiedenis met beklemtoning van groot lewensvraagstukke." ${ }^{{ }^{43}}$

Ofskoon die krygsgeskiedenisleerplanne ${ }^{44}$ geen direkte melding van temas soos militêre professionalisme en die militêr en die gemeenskap gemaak het nie, het hierdie doelformulering oorlogvoering tog binne die nasionale (hoewel blank gesentreerde) en internasionale omgewing in perspektief geplaas ("wêreldorganisasie", "internasionale verhoudings", "nasionale geskiedenis", "groot lewensvraagstukke"). Dit het ook die kwessie van sosiale verpligting, patriotisme, lojaliteit en militêre eer wat met militêre professionalisme verbind word, aangesny ("besiel met die ideaal om hul land te eer en dien").

Met verskuiwing van die Militêre Akademie na Stellenbosch (1955/56) en Saldanha $(1957 / 8),{ }^{45}$ is daar, wat die Krygsgeskiedenisleerplanne betref, onder die vaandel van die Universiteit van Stellenbosch voortgebou op die grondslag wat aan die Universiteit van Pretoria gelê is. Die ewolusie van oorlogvoering was steeds die sentrale tema, maar met die nodige klem op die konteks waarbinne dit bestudeer moet word. Kmdt. (dr.) C.M.

42 UP Argief, Notule Raad van UP, 1954 Deel I (Jan.-Jun.), S.92, Notule van gewone vergadering van die Senaat gehou op 17 Mrt. 1954 om 2.30 nm., 11-12; UP Argief, Notule Raad van UP, 1954 Deel I (Jan.-Jun.), S.256, Fakulteit Wis- en Natuurkunde : Voorgestelde Regulasiewysigings en Leerplanne, 2-3; UP Biblioteek, Universiteit van Pretoria Jaarboek 1955, 170-171.

43 SANWA, S.A. Mil. Kol. (Groep 1) 87, MK/F/9/1, inlae 16, brief MK/F/9/1, 4 Des. 1953, Kmdt. S.A. Mil. Kol. -A.L. Kotzee, Buro van Opvoedkundige en Maatskaplike Navorsing, Dept. van Onderwys, Kuns en Wetenskap.

44 UP Argief, Notule van die Raad van die Universiteit van Pretoria, 1951, dokument S. 7613 dd 21 Feb. 1951, 'Hersiene Leerplan: Militêre Geskiedenis'; SANWA, SAMil Kol (Gp 1) 87, MK/F/9/1, inlae 16, brief MK/F/9/ 1 dd 4 Des. 1953, Kmdt. SA Mil Kol - A.L. Kotzee, Buro van Opvoedkundige en Maatskaplike Navorsing, Dept. van Onderwys, Kuns en Wetenskap.

45 C.M. Bakkes, 'Die Geskiedenis van die Militêre Akademie te Pretoria (Apr. 1950-Feb. 1956)', in E.M. Muller, et. al., reds., Militêre Akademie 1950-1975: Silwerjubileum (Saldanha, 1975), 7-13; P.J.G. de Vos, 'Die Militêre Akademie, 1956-1967', in Muller, et. al., Militêre Akademie 1950-1975, 15, 17, 21. 
Bakkes, jarelange (1954-69) dosent in Krygsgeskiedenis aan die Militêre Akademie en grondlegger van dié vak as selfstandige universiteitsvak hier te lande, ${ }^{46}$ het die aard en wese van die vak in 1967 soos volg beskryf:

"Die vak ... ondersoek die ewige verandering wat die verskynsels oorlog en oorlogvoering ondergaan ... geprojekteer teen die doek wat gevorm word deur die algemene geskiedenis ... en volg die ontwikkelingsgang daarvan tot op datum ... om die redes vir die oorwinning en neerlaag bloot te lê en in krygskundige norme saam te vat sodat die aankweek van militêre insig by die student wat oorlogvoering bestudeer, bespoedig kan word ...."47

Gebou op hierdie vaste fondament, wat die krygsgeskiedenis as hoeksteen van militêre professionalisme tot sy reg laat kom, is die aard en doel van krygsgeskiedenisonderrig aan die Militêre Akademie teen 1994 soos volg omskryf:

"Die vak Krygsgeskiedenis behels ' $n$ tematies-chronologiese studie van die evolusie van oorlogvoering van die antieke tot die kontemporêre tyd. Die onderrig van die vak behels eerstens die verskaffing van ' $n$ verwysingsraamwerk ten opsigte van die oorsake, verloop en gevolge van die oorloë van die verlede. Verder word die student onderrig in die ontwikkeling van die militêre professie ten opsigte van bevelvoering en stafwerk, soos verpersoonlik deur die groot veldhere, die verdedigingen vapenstelsels en die strategie en taktiek wat in bepaalde tydperke aangewend is. Verdere aspekte wat aandag geniet, is die ontwikkeling van die logistieke, kommunikasie- en inligtingstelsels van leërs, vlote en lugmagte in verskillende tydperke in die geskiedenis. Laastens word die ontwikkeling van militêre denke en die verhouding tussen weermagte en gemeenskappe deur die eeue bestudeer." 48

Hoewel Krygsgeskiedenis as vak, wat inhoud en sofistikasie betref, onder die vaandel van die Universiteit van Stellenbosch duidelike groei en vooruitgang getoon het, het die vak sy sentrale, samebindende posisie in die militêre graadkursusse heeltemal verloor, deurdat dit uit die staanspoor nie vir alle militêre studente ' $n$ verpligte vak was nie. Voor die totstandkoming van die Militêre Akademie as volwaardige Fakulteit Krygskunde van die Universiteit van Stellenbosch in Januarie 1961, moes alle militêre studente hul eerstejaar op die kampus van die Universiteit van Stellenbosch deurbring, waar hulle dieselfde vakke

46 J.S. Kotze, 'Die Onderrig van Krygsgeskiedenis in Suid-Afrika: Uitdagings vir die Negentigerjare', referaat gelewer tydens die 15 de Tweejaarlikse Konferensie van die Suid-Afrikaanse Historiese Vereniging, Grahamstown, 2-5 Jul. 1995, 4.

47 SANWA, Hoof van Staf Personeel (Geklassifiseerd) 10, HWA 599/2/12/3 vol. 1, inlae 23, memorandum deur kmdt. C.M. Bakkes 'Wat is Geskiedenis Mil I, II, en III,' aangeheg by brief G/TRG/1/0, 9 Nov. 1967, Bevelvoerder Militêre Akademie (Bev. Mil. Akad.) - veggenl. C.H. Hartzenberg, Voorsitter Raad op Offisiersopleiding. Dept. Krygsgeskiedenis, Fakulteit Krygskunde, US, ongepubliseerde inligtingstuk, 1994, 1.

49 SANWA, Kommandant-Generaal (K.G.) K43 L81, KG/GPT/1/3/1/1 vol. 5, inlae 2, memorandum deur kol P.J.G. de Vos betreffende eerstejaar-B.Mil.-opvoeding aan die Militêre Akademie aangeheg by brief G/TRG/6/2, 28 Mei 1957, Bev. Mil. Akad. - K.G.; P.J.G. de Vos, 'Die Militêre Akademie, 1956-1967', 15, 21, 23. 
as die burgerlike studente geloop het. ${ }^{49}$ Diegene wat die B.Mil.-graad in die Natuurwetenskappe (aanvanklik bekend as die B.Sc.(Mil.) ) gevolg het, kon glad nie Geskiedenis of Krygsgeskiedenis neem nie. ${ }^{50}$ Met die instelling van 'n B.Mil.-graad in die Handelswetenskappe in 1961, is daar ook nie voorsiening daarvoor gemaak dat studente wat dié kursus wou volg, Krygsgeskiedenis as vak kon loop nie. ${ }^{51}$ Geskiedenis I (d.w.s. gewone Geskiedenis, soos ook deur die burgerlike studente geloop) en Krygsgeskiedenis II (oftewel Geskiedenis II (Mil.), soos dit toe genoem is) was onder die nuwe bedeling verpligtend vir die B.Mil.-graad in die Geesteswetenskappe (aanvanklik bekend as die B.A.(Mil.)). (Die Vlootstudente moes aanvanklik klaarblyklik almal die B.Mil. in die Natuurwetenskappe volg en kon dus glad nie Krygsgeskiedenis loop nie. ${ }^{52}$ Dié toedrag van sake het egter in 1956 verander, sodat Vlootstudente ook die B.Mil. in die Geesteswetenskappe kon loop, met Krygsgeskiedenis as ' $n$ verpligte vak op eerstejaarsvlak. ${ }^{53}$ ) Slegs Leërstudente kon aanvanklik Krygsgeskiedenis (as 'n keusevak) op derdejaarsvlak loop, maar teen 1959 kon studente van al drie Weermagsdele dit wel as keusevak tot op derdejaarsvlak volg. Krygsgeskiedenis II was egter in daardie stadium reeds net vir Leërstudente verpligtend en teen 1963 het dit ook vir hulle op tweedejaarsvlak 'n keusevak geword. Krygsgeskiedenis was dus teen 1963 net in die B.Mil. (Geesteswetenskappe), en wel slegs op eerstejaarsvlak, vir die studente van al drie Weermagsdele verpligtend, maar daarna was dit 'n keusevak. ${ }^{54}$

Die verminderde klem op die krygsgeskiedenis kan miskien verklaar word deur die opvatting wat die destydse Leërstafhoof, veggenl. S.A. Engelbrecht, met betrekking tot die waarde van dié, vak gehuldig het:

"Kennis van die landsgeskiedenis en Militêre Geskiedenis is van groot waarde vir enige offisier. As hoofvak mag die onmiddellike waarde van Geskiedenis beperk wees, behalwe vir offisiere wat as argivarisse opgelei gaan word." "5s

Die destydse Dekaan en Bevelvoerder van die Militêre Akademie, kol. (prof.) P.J.G. de Vos ('n natuurwetenskaplike), het op sy beurt uit 'n beroepsoogpunt weinig nut in ' $n$ studie van die krygsgeskiedenis bokant honneursvlak gesien:

so SANWA, A.G.(3) 227, AG(3) 1906/9 vol. VII, inlae la, Verslag van samesprekings tussen die sameroeper van die Eksamen- en Promosiebepalingskomitee (prof. J.P. Yeats) en verteenwoordigers van die Militêre Akademie i.s. eksamen- en promosiebepalings vir die B.Mil.-graad gehou op 28 Sept. 1956; SANWA, A.G.(3) 225 , AG(3) 1906/9 vol. 8, inlae 2, brief DGAF/SOVD/203/7/1/TR, 21 Aug. 1957, Waamemende Lugstafhoof - AdjudantGeneraal (A.G.); Universiteit van Stellenbosch Jaarboek 1956 Deel 1, 163-164.

51 SANWA, A.G.(3) 225, AG(3) 1906/9 vol. 9, inlae 34, brief AG 213/14/113 oor AG 950/3 en AG(3) 1906/9, 30 Sept. 1960, A.G. - Sekretaris van Verdediging; Universiteit van Stellenbosch Jaarboek 1962, 500.

52 SANWA, A.G.(3) 227, AG(3) 1906/9 vol. VII, inlae la, Verslag van samesprekings tussen die sameroeper van die Eksamen-en Promosiebepalingskomitee (prof. J.P. Yeats) en verteenwoordigers van die Militêre Akademie i.s. eksamen- en promosiebepalings vir die B.Mil.-graad gehou op 28 Sept. 1956 :

53. Universiteit van Stellenbosch Jaarboek 1956 Deel 1, 163-164.

54 Universiteit van Stellenbosch Jaarboek 1956 Deel 1, 163-164; Universiteit van Stellenbosch Jaarboek 1959, 211-13.; Universiteit van Stellenbosch Jaarboek 1963, 527-30.

s5 SANWA, K.G. K43 L81, KG/GPT/1/3/1/1 vol. 6, inlae 66, brief G/TRG/6/2, 13 Sept. 1962, Leërstafhoof - Bev. Mil. Akad. 
"Wat nagraadse Geskiedenisstudie betref word besef dat die doel van die studie in die eerste plek is om nog bekwamer militêre leiers te kweek en nie militêre historici nie. Wat die honneurstudie betref word gevoel dat dit tog aan hierdie primêre doel beantwoord veral as dit aan die Akademie plaasvind. Dit is egter te betwyfel of die M-Mil (sic) verhandeling in Militêre Geskiedenis op hierdie tydstip 'n ekonomiese besteding van die tyd van ' $n$ offisier sal wees. So 'n offisier wat in Geskiedenisnavorsing onderleg is, sal moontlik by aftrede waardevolle werk kan doen in die nasionale taak van Militêre Geskiedskrywing waaraan in Suid-Afrika nog baie min gedoen is." $\$ 6$

Krygsgeskiedenis het dus binne 'n rapsie meer as ' $n$ dekade ná die stigting van die Militêre Akademie sy sentrale, samebindende rol in die militêre graadkursusse verloor, klaarblyklik omdat daar in die destydse Suid-Afrikaanse Weermag, minstens in soverre dit formele onderrig in die vak betref, nie meer soveel ag op die waarde daarvan uit die oogpunt van militêre professionalisme geslaan is nie; sleutelfigure soos die Leërstafhoof en die Dekaan en Bevelvoerder van die Militêre Akademie, het oënskynlik nie besef watter rol ' $n$ diepere studie van die krygsgeskiedenis kon speel om die professionele denke van die offisier te vorm en te stimuleer nie.

'n Tydelike kentering in die rol van die krygsgeskiedenis in offisiersopvoeding in SuidAfrika het in 1970 plaasgevind, toe 'n nuwe offisiersopleidingstelsel vir die S.A. Staande Mag in werking gestel is op grond van 'n model wat brig. (later genl.) M.A. de M. Malan, destydse bevelvoerder van die Militêre Akademie, ontwerp het. Volgens dié model het alle aspirantoffisiere hul basiese vormingsopleiding by die Militêre Akademie ontvang, ${ }^{57}$ en was Krygsgeskiedenis ' $n$ verpligte vak op dié kursus. Brig. Malan het Krygsgeskiedenis en Staatsleer naamlik as "grondliggend" vir die "wetenskaplike vorming" van offisiere beskou. ${ }^{58}$ Dié twee vakke is op eerstejaarsvlak aangebied en diegene wat ná hul vormingskursus met graadstudie aan die Militêre Akademie wou voortgaan en die vak vir graaddoeleindes erken wou hê, moes aan die slaagvereistes van die Universiteit van Stellenbosch voldoen. Wat die graadkursus as sodanig betref, het diegene wat in die Natuur- en Handelswetenskappe studeer het, Krygsgeskiedenis dus as ' $n$ vepligte vak in hul eerstejaar geloop, maar kon dit nie op tweede- en derdejaarsvlak voorsit nie. Diegene wat die Geesteswetenskaplike rigting gevolg het, kon dit wel as ' $n$ keusevak op tweede- en derdejaarsvlak

56 A.G.

57 


\section{voortsit. $^{59}$}

Die doel met die onderrig van Krygsgeskiedenis gedurende bovermelde vormingskursus was om "... toekomstige offisiere vertroud te maak met die evolusie van oorlogvoering en hulle ' $n$ bondige oorsig te gee van elke weermagsdeel se geskiedenis - met besondere verwysing na dié in die RSA." ${ }^{60}$ Daar sou in dié proses in die besonder ook aandag geskenk word aan die beginsels van oorlogvoering. ${ }^{61}$ Hoewel die onderrig van Krygsgeskiedenis onder hierdie bedeling duidelik sterk op die praktiese nutswaarde van die vak gerig was, het die studie van krygsgeskiedenis minstens hiermee in ' $n$ mate sy sentrale posisie in offisiersopvoeding herwin, soos wat die eise van militêre professionalisme dikteer.

Die herinstelling van Krygsgeskiedenis as verpligte vak vir alle studente by die Akademie was egter van korte duur. Gedurende 1975/76 is die vormingsopleiding van offisiere weer van die Akademie na die Weermagsdele terugverskuif, klaarblyklik omdat die Akademie té Leër-georiënteerd was en die vormingsopleiding dus nie die behoeftes van die Lugmag en Vloot volkome bevredig het nie. ${ }^{62}$ Daarmee het die verpligte onderrig van Krygsgeskiedenis vir alle aspirantoffisiere van die destydse Suid-Afrikaanse Weermag weer tot 'n einde gekom. Wat die militêre graadkursusse betref, is die vak Krygsgeskiedenis daarmee in sy swakste posisie ooit gedompel, deurdat dit sedert 1977 nie meer 'n verpligte vak op enige vlak in enige studierigting is nie. ${ }^{63}$

Die feit dat Krygsgeskiedenis sy status as verpligte vak verloor het, kan waarskynlik daaraan gewyt word dat brig. Malan in daardie stadium nie meer bevelvoerder van die Akademie was nie en dus nie sy persoonlike invloed direk kon laat geld nie; hy was persoonlik diep oortuig daarvan dat Krygsgeskiedenis ' $n$ verpligte vak by die Akademie moes wees. ${ }^{64}$

Teen die begin van 1990 het die Verdedigingsbevelsraad op aandrang van genl. J.J. Geldenhuys, die destydse Hoof van die SA Weermag, wat persoonlik baie waarde aan ' $\mathrm{n}$ studie van die krygsgeskiedenis geheg het, ${ }^{65}$ 'n poging aangewend om Krygsgeskiedenis weer verpligtend vir alle studente aan die Militêre Akademie te maak, ongeag hul studierigtings. Die Verdedigingsbevelsraad se riglyne in dié verband het volgens kol. J.S. Kotze, destyds Hoof van die Afdeling Geesteswetenskappe en professor in Krygsgeskiedenis aan die Militêre Akademie, se interpretasie daarvan, daarop neergekom dat Krygsgeskiedenis

Mil. Akad. Argief, Verslag oor die Militêre Akademie Deel I, 28 Feb. 1968, Aanhangsel E, 16.

Mil. Akad. Argief, Verslag oor die Militêre Akademie Deel I, 28 Feb. 1968, Aanhangsel E, 16.

62 SANWA, Mil. Akad. (Groep 3) 146, G/SD/3/1/20 (Vertroulik) vol. I, inlae 25, brief G/SD/3/1/20 oor G/TRG/6/ 2/0, 8 Sept. 1975, Bev. Mil. Akad. - Hoof van Staf Personeel; Mil. Akad. Argief, verslag deur L.J. du Toit (Direktoraat Sielkundige Dienste, Geneesheer-generaal, SAW), Mrt. 1974, 169-170; Mil. Akad. Argief, Verslag deur Komitee van Ondersoek (voorsitter: kol. P.W. van der Westhuizen) mbt Jongoffisiersopleiding te Militêre Akademie Saldanha, 31 Jan. 1975, 18-32, 38, 21-24, 41-43, 49-50, 55-56.

63 Vergelyk Universiteit van Stellenbosch Jaarboek 1977 Deel 13: Fakulteit Krygskunde en Universiteit van Stellenbosch Jaarboek Deel 14: Fakulteit Krygskunde, 1978-1995.

64 Onderhoud Visser - Malan, Pretoria, 24 Nov. 1994.

65 Telefoniese onderhoud G.E. Visser - J.J. Geldenhuys, 28 Aug. 1997.
} 
"n praktiese vak moes wees wat die student "moet leer hoe om oorlog te maak"; dat die doel van Krygsgeskiedenis dus moes wees om lesse uit die verlede te leer, waarmee hedendaagse probleme opgelos kon word; en dat die bestaande Krygsgeskiedenisleerplanne, wat ' $n$ chronologiese studie van die ewolusie van oorlogvoering (binne die breër politieke, ekonomiese en sosiale konteks) behels het, nie vir bogenoemde doeleindes geskik was nie en dat Krygsgeskiedenis dus na Strategiese Studie moes ontwikkel. Die implikasie van die Verdedigingsbevelsraad se riglyne vir die vak Krygsgeskiedenis was volgens Kotze só ingrypend, dat dit die aard en wese, en ook die wetenskaplikheid, van die vak sou aantas ${ }^{66}$ Dit het daartoe gelei dat 'n nuwe vak, Militêre Strategie, met ingang van 1991 by die Fakulteit Krygskunde ingestel is, ${ }^{67}$ wat bovermelde behoeftes van die Weermag sover moontlik sou bevredig. ${ }^{68}$ Voorgeskrewe modules van dié vak het dan ook verpligtend vir alle studente in al drie studierigtings aan die Militêre Akademie geword. ${ }^{69}$

Dit is in die lig van die voorafgaande duidelik dat daar sedert die stigting van die Militêre Akademie heeltemal wegbeweeg is van die benadering dat Krygsgeskiedenis, as steunpilaar van offisiersopvoeding en militêre professionalisme, die samebindende element van alle militêre graadkursusse moet wees. 'n Interdissiplinêre vak, Militêre Strategie, wat wel raakvlakke met Krygsgeskiedenis het, en inderdaad logieserwys stewig op die krygsgeskiedenis gegrond behoort te wees, maar volgens skrywer nie Krygsgeskiedenis as rigsnoer vir militêre professionalisme kan vervang nie, het nou die sentrale posisie in die militêre graadkursusse ingeneem.

\section{DIE ONDERRIG VAN KRYGSGESKIEDENIS IN DIE VOORMALIGE S.A.W. BUITE DIE MILITÊRE AKADEMIE}

Die Militêre Akademie was vanaf sy stigting in 1950 nie die enigste weg na offisiersaanstelling nie, ${ }^{70}$ sodat alle offisiere van die Unieverdedigingsmag dus nie op universiteitsvlak aan onderrig in die krygsgeskiedenis blootgestel is nie. Daar is egter in 'n mate daarvoor vergoed, deurdat offisiere wat bevorderingskursusse by die S.A. Militêre Kollege Mei 1990, Afdelingshoof Geesteswetenskappe - Dekaan Fakulteit Krygskunde.

67 Mei 1990, Afdelingshoof Geesteswetenskappe - Dekaan Fakulteit Krygskunde; Die Universiteit van Stellenbosch Jaarboek 1991-92 Deel 14: Fakulteit Krygskunde, 3-6. Mei 1990, Afdelingshoof Geesteswetenskappe - Dekaan Fakulteit Krygskunde.

Die Universiteit van Stellenbosch Jaarboek 1991-92 Deel 14: Fakulteit Krygskunde, 3-6; Universiteit van Stellenbosch Jaarboek 1993-4 Deel 14: Fakulteit Krygskunde, 3-6.

Bakkes, 'Die Geskiedenis van die Militêre Akademie te Pretoria (Apr. 1950-Feb. 1956)',9.

SANWA, S.A. Mil. Kol. (Groep 1) 87, MK/F/9/1, inlae 16, briefMK/F/9/1,4 Des. 1953, Kmdt. S.A. Mil. Kol. - A.L. Kotzee, Buro van Opvoedkundige en Maatskaplike Navorsing, Dept. van Onderwys, Kuns en Wetenskap; Onderhoud G.E. Visser - C.M. Bakkes, Pretoria, 29 Jul. 1993; Telefoniese gesprek G.E. Visser - C.M. Bakkes, 7 Apr. 1995. 
bygewoon het, ook onderrig in die krygsgeskiedenis ontvang het. ${ }^{71}$ Dié praktyk is mettertyd uitgebrei, sodat krygsgeskiedenis byvoorbeeld ook by die S.A. Leër se Stafdienskursusse aan die S.A. Militêre Kollege (tans die S.A. Leërkollege) aangebied is. Dosente van die Militêre Akademie het dikwels gedurende resestye met die aanbied van krygsgeskiedenis by laasgenoemde kursusse gehelp. ${ }^{72}$

Die onderrig van krygsgeskiedenis in die Suid-Afrikaanse Weermag buite die Militêre Akademie het egter ook sedert die vyftiger- en sestigerjare ' $n$ kreeftegang gegaan. Daar is sedertdien wel op ' $n$ gefragmenteerde wyse onderrig in die krygsgeskiedenis by wyse van werkopdragte en gevallestudies by sommige vormings- en bevel- en stafkursusse aangebied, ${ }^{73}$ maar van doelgerigte, sistematiese onderrig in die krygsgeskiedenis, was daar in dié verband in die Suid-Afrikaanse Weermag teen 1994 geen sprake nie.

\section{DIE ONDERRIG VAN KRYGSGESKIEDENIS IN UMKHONTO WESIZWE}

Die offisiere van MK en die ander niestatutêre magte wat in 1994 saam met die voormalige SAW en ander statutêre magte in die SANW opgeneem is, kan vanweë hul (rewolusionêre) guerrilla-agtergrond nie sonder meer aan die norme van militêre professionalisme wat hierbo uiteengesit is, gemeet word nie. Dit is egter insiggewend om daarop te let dat hulle ook ' $n$ tradisie van die bestudering van die krygsgeskiedenis saam met hulle in die SANW ingedra het. ANC-leier, Govan Mbeki, wys daarop dat die ANC- en SAKPleierskap Mao Tse Tung en Che Guevara se teorieë van guerrilla-oorlogvoering bestudeer het, voordat hulle teen die einde van 1961 besluit het om die wapen op te neem en tot die stigting van MK oor te gaan. ${ }^{74}$ Ronnie Kasrils, voormalige MK-intelligensiehoof en teenswoordige Adjunkminister van Verdediging, vertel ook hoedat ANC-leier Oliver Tambo, hom en die latere MK-bevelvoerder, Chris Hani, in die vroeë sestigerjare na die ANC-kantoor in Dar-es-Salaam ontbied het en opdrag gegee het om ' $n$ reeks boeke oor guerrilla- en teeninsurgensie-oorlogvoering te bestudeer. ${ }^{75}$ Kasrils meld ook dat Guevara by daardie geleentheid persoonlik in Dar-es-Salaam besoek afgelê het, waar hy leiers en ander lede van die ANC en ander bevrydingsbewegings in die Kubaanse ambassade oor guerrillaoor-logvoering toegespreek het. ${ }^{76}$

Volgens genl.-maj. A.M.L. Masondo, voormalige Nasionale Kommissaris van MK en

72 SANWA, Mil. Akad. (Groep 1) 15, G/TRG/6, inlae 5 brief G/TRG/6 oor G/TRG/6/19, 26 Okt. 1964, Kmdt. S.A. Mil. Kol. - Leërstafhoof; Onderhoud Visser - Bakkes, Pretoria, 29 Jul. 1993; Telefoniese gesprek Visser - Bakkes, 7 Apr. 1995.

7 Kotze, 'Die Onderrig van Krygsgeskiedenis in Suid-Afrika', 1-2; Gesprek G.E. Visser - kol. J.A. van Tonder (Bevelvoerder Militêre Opleiding, Militêre Akademie) op grond van mondelinge terugvoer wat laasgenoemde van die S.A. Leër se opleidingsinrigtings oor die onderrig van krygsgeskiedenis gekry het, 4 Jan. 1996.

74 G. Mbeki, The Struggle for Liberation in South Africa: A Short History (Cape Town, 1992), 89.

75 R. Kasrils, 'Armed and Dangerous': My Undercover Struggle Against Apartheid (Gaborone, etc, 1993), 95, 96.

76 Kasrils, 'Armed and Dangerous', 97 - 98. 
tans Direkteur Korporatiewe Kommunikasie van die SANW, het MK sillabusse vir die onderrig van krygsgeskiedenis op verskillende vlakke gehad. Hy sê in dié verband:

"When we were teaching the struggle, military history became part of the struggle ... we did, for instance, the history of guerrilla warfare, we started, for instance, (with) Che Guevara, Giap and also Mao Tse Tung ... You also studied other revolutions, like the Algerian Revolution ... You studied the struggle, so that in a way you studied military history as part of ... guerrilla warfare, as part of ... the revolutionary field ... we did not call it military history; we called it the history of the struggle, but within it was military history ..." 77

MK het egter nie net die geskiedenis van rewolusionêre guerrilla-oorlogvoering bestudeer nie; hulle het ook die krygsgeskiedenis van swart mense in Suid-Afrika, met besondere verwysing na bekende militêre leiers soos Shaka, Maqoma en Adam Kok, en swart oorwinnings, soos die Slag van Isandlwana, bestudeer. Die gedagte daarmee was om aan swart mense te toon dat hulle 'n geskiedenis van oorlogvoering, militêre leierskap en oorwinning gehad het en hulle hulle dus suksesvol tot die gewapende stryd kon wend om hul politieke vryheid te verkry. ${ }^{78}$

Die ANC en MK was indertyd waarskynlik eerder op die instruksionele en propaganda-waarde van die krygsgeskiedenis, as op die bewustelike nastrewing van militêre professiona-lisme, soos hierbo uiteengesit, ingestel. Masondo bring nietemin (weliswaar uit ' $n$ agterna-perspektief en op 'n direkte vraag in dié verband) tog beide hul studie van rewolusionêre guerillaoorlogvoering en swart krygsgeskiedenis in Suid-Afrika met militêre professionalis-me in verband. Hy stel dit soos volg:

“... military history is a necessary condition for professionalism ... it will teach the traditions, it will teach you how ... throughout the history of mankind, the pro-

fessionals related to the people ... Things like bravery, courage and all those are part of professionalism ..." 79

Ofskoon die MK-offisiere en die offisiere van die ander niestatutêre magte wat in 1994 tot die SANW toegetree het, nie professionele staandemagoffisiere in die konvensionele sin van die woord was nie, was hulle dus nie totaal onbekend met die norme van militêre professionalisme en die bestudering van die krygsgeskiedenis vanuit daardie oogpunt nie.

\section{DIE ONDERRIG VAN KRYGSGESKIEDENIS IN DIE S.A. NASIONALE WEERMAG SEDERT 1994}

Die totstandkoming van die SANW op 27 April 1994, het geen verandering in die status van Krygsgeskiedenis as vak by die Militêre Akademie teweeggebring nie; dit is

\footnotetext{
77 Onderhoud G.E. Visser - A.M.L. Masondo, Pretoria, 7 Feb. 1997.

78 Onderhoud Visser - Masondo, Pretoria, 7 Feb. 1997.

79 Onderhoud Visser - Masondo, Pretoria, 7 Feb. 1997.
} 
steeds nie op enige vlak vir enige studierigting verpligtend nie. Die basiese filosofie wat die onderrig van die vak ten grondslag lê, het ook nie verander nie. Soos uit onderstaande aanhaling blyk, word militêre professionalisme egter tans pertinent in die formulering van die onderrigfilosofie van die vak verwoord en word meer klem op voorgraadse vlak op die teorie van Krygsgeskiedenis gelê, waar laasgenoemde voorheen hoofsaaklik op honneursvlak tereggekom het:

"Aandag word ook geskenk aan ... kontemporêre opvattings oor militêre professionalisme en die rol van die militêr in 'n demokratiese gemeenskap. Laastens word die grondbeginsels van die Krygsgeskiedenis as wetenskap by die student ingeskerp ..." 80

Die onderrig van krygsgeskiedenis buite die Militêre Akademie het wel sedert die totstandkoming van die SANW 'n positiewe ontwikkeling getoon. Daar is naamlik tydens ' interkollegekonferensie van die SANW gedurende 14 - 18 Oktober 1996 besluit dat onderrig in krygsgeskiedenis "... reeds van junior offisiersopleiding af deel (moet) wees van die opvoeding van die offisier" en dat "... stafkolleges ... meer aandag (moet) bestee aan krygsgeskiedenis, veral Suid-Afrikaanse krygsgeskiedenis." ${ }^{11}$ Die implementering van hierdie besluite, spesifiek wat die inhoud van die Krygsgeskiedenismodules van die verskillende kursusse moet behels, word tans in samewerking met die Departement Krygsgeskiedenis van die Militêre Akademie ondersoek. ${ }^{82}$ Die gedagte is om SANW-offisiere tot lewenslange studie van die krygsgeskiedenis te motiveer, deur hul belangstelling in die vak te prikkel en hulle bewus te maak van die waarde van die krygsgeskiedenis vir hul professie. ${ }^{83}$

\section{SLOT}

Die krygsgeskiedenis is die hoofbron van militêre kennis en word derhalwe wêreldwyd in die nastrewing van militêre professionalisme bestudeer. Die SANW en sy voorgangers het insgelyks histories deurlopend aandag aan die bestudering van die krygsgeskiedenis geskenk, maar daar het duidelik 'n vervlakking in dié verband gedurende die afgelope paar dekades ingetree. Tans word die onderrig van krygsgeskiedenis egter opnuut deur die verskillende Weermagkolleges onder die loep geneem, met die oog daarop om dit op ' $n$ meer sistematiese wyse by die totale offisiersontwikkelingsprogram in te skakel. Die behoorlike

80 Dept. Krygsgeskiedenis, Fakulteit Krygskunde, US, ongepubliseerde inligtingstuk, 'Aard en Doel van Krygsgeskiedenis', 1997,1.

81 Mil. Akad. lopende argief, MA/B/522/1 Deel 4, inlae 15, Notule van 'n Interkollegekonferensie gehou by die SA Leërkollege van 14 tot 18 Okt. 1996, 8 - 9.

82 Mil. Akad. lopende argief, MA/B/522/1 Deel 4, inlae 48, Notule van ' $n$ Interkollegekonferensie gehou by die SA Verdedigingskollege op 3 Apr. 1997, 4.

83 Mil. Akad. lopende argief, MA/B/522/1 Deel 4, inlae 48, voorlegging deur Dept. Krygsgeskiedenis aangeheg by notule van ' $\mathrm{n}$ interkollegekonferensie gehou by die SA Verdedigingskollege op 3 Apr. 1997. 
implementering van dié plan in oorleg met die Departement Krygsgeskiedenis aan die Militêre Akademie, sal die SANW in daardie opsig met die gebruik in ander moderne weermagte, sowel as die eise van militêre professionalisme, in pas bring.

Die grootste knoop lê tans by die status van Krygsgeskiedenis as vak by die Militêre Akademie. Krygsgeskiedenis was histories 'n verpligte vak vir alle studente aan die Militêre Akademie en was die fondament waarop offisiersopvoeding aan dié instelling gebou is; dit het die agtergrond gevorm waarteen alle ander akademiese dissiplines bestudeer is. Vandag voldoen die onderrigfilosofie en leerplaninhoude van die Departement Krygsgeskiedenis aan die Militêre Akademie steeds aan die eise van militêre professionalisme, maar Krygsgeskiedenis is nie meer ' $n$ verpligte vak by dié instelling nie. Militêre Strategie, ' $n$ interdissiplinêre vak wat logieserwys diep wortels in die krygsgeskiedenis het, maar nie Krygsgeskiedenis as rigsnoer vir militêre professionalisme kan vervang nie, het nou die sentrale posisie as verpligte vak in die militêre graadkursusse ingeneem. Dié toedrag van sake kom daarop neer dat daar in die SANW, strydig met die praktyk in ander moderne weermagte, nie volle erkenning verleen word aan die sleutelposisie wat 'n kennis van die krygsgeskiedenis ten opsigte van militêre professionalisme beklee nie.

Die handjievol offisiere wat Krygsgeskiedenis as keusevak by die Militêre Akademie loop, is eenvoudig nie genoeg om die arms van die ganse offisierskorps omhoog te hou nie. Krygsgeskiedenis behoort weer ' $n$ verpligte vak vir alle voorgraadse studente by die Akademie te word. Die ideaal sal waarskynlik wees om die vak Militêre Stategie by Krygsgeskiedenis te inkorporeer; ' $n$ studie van die krygsgeskiedenis sonder voldoende aandag aan militêre strategie is immers ondenkbaar is, terwyl 'n studie van militêre strategie op sy beurt die krygsgeskiedenis as basis behoort te hê. 'n Diepere studie van militêre strategie op die meer teoreties-filosofiese vlak behoort hoofsaaklik op nagraadse vlak tereg te kom, aangesien die multidissiplinêre aard van die vakgebied ' $n$ breër akademiese agtergrond vereis as waaroor die gemiddelde voorgraadse student beskik. Met Krygsgeskiedenis as hoofvak, kan 'n student dan toegelaat word tot honneursstudie in òf Krygsgeskiedenis, ò Militêre Strategie, òf ' $n$ kombinasie van die twee.

Die herinstelling van Krygsgeskiedenis as verpligte voorgraadse vak by die Militêre Akademie sal nie alleen die eis van ware militêre professionalisme dat die krygsgeskiedenis ook op universiteitsvlak bestudeer behoort te word, bevredig nie; dit sal ook die SANW van 'n poel van gegradueerde offisiere met genoegsame kennis van (en 'n wetenskaplike benadering tot) die krygsgeskiedenis voorsien om die bestudering van die vak by ander opleidingsinstansies in die SANW te optimaliseer. Langs dié weg sal militêre professionalisme dwarsdeur die Weermag uitgebou word en SANW-lede in staat gestel word om hulle te handhaaf in ' $n$ internasionale milieu waar ' $n$ grondige kennis van die krygsgeskiedenis as ' $n$ vanselfsprekende element van die offisier se professionele mondering aanvaar word. 